\title{
Human responsibility towards environment in the Quran
}

\author{
Deni Wahyudi Kurniawan \\ Program Manager of Indonesia Inst itute for Social Development, Jakarta \\ E-mail:deni.wk@gmail.com
}

\begin{abstract}
The research aims to describe the view of Islam about human relation with the environment according to the verses related to the duties and functions of the human being. This is interesting issue in the middle of allegations that the religion and the human perspective is one of the roots of the ecological crises that happen in the world. By doing research on verses on the concept of human being, concept of the environment and interaction between human the environtment, wil be drawn islamic teachings on relationship between human being and the environment. The research will figure out comprehensive islamic concept on the functions and duties of human being toward environment. Islam believes that man and nature are interdependent and has an obligation to maintain the balance of nature as manifestation of the faith and at the same time as his mission as 'abdullāh and successor of god (khalifatulläh) the earth.
\end{abstract}

Kajian dalam artikel ini bertujuan untuk menguraikan pandangan Islam mengenai interaksi manusia dengan lingkungan hidup menurut ayat-ayat terkait tugas dan fungsi manusia. Isu ini menarik di tengah tuduhan bahwa agama dan cara pandang manusia merupakan salah satu akar dari berbagai krisis ekologis yang dihadapi oleh dunia. Dengan melakukan kajian terhadap ayat-ayat fungsi dan tugas manusia, pengertian lingkungan hidup dan interaksi antara manusia dan lingkuangannya akan tergambar ajaran islam tentang hubungan antara manusia dengan 
lingkungan hidup. Dengan menguraikan ayat-ayat yang membahas fungsi dan tugas manusia serta ayat yang terkait lingkungan hidup akan tergambar bahwa Islam memiliki pandangan yang komprehensif mengenai hubungan mansuia dan lingkungan hidup dan tugas-tugasnya. Islam memandang bahwa manusia dan alam merupakan satu kesatuan dan saling tergantung serta memiliki kewajiban untuk menjaga keseimbangan sebagai manifestasi dari keimanan seorang hamba sebagai 'abdullāh dan khalifah di muka bumi.

Keywords: Insān; Environment; Khalifah; Human being

\section{Introduction}

The environmental damage has reached a serious degree, for example in one year (1997-1998) more than 25 million hectares forest was burnt in all over the world because of the El Nino. In Indonesia forest fire had burnt more than 9 million hectares and lead to 24 million billion dollars loss. ${ }^{1}$ The International Federation of Red Cross and Red Crescent Societies (IFRCRCS) report shows that from 1999 until 2008 had occurred 7.191 disasters, means that every year 799 disaster happen in the world including droughts, earthquakes, floods, and others. Those disasters have killed 1.243 .480 people, affected to 2.695.813.000 peoples and had caused material loss more than 1.082.391 million US dollars. ${ }^{2}$

One of the reasons for the increasing number of disasters in the world is the process of resource exploitation. This destructive process is one which cause the imbalance of the environment that lead to global warming and climate change due to the combustion process from cars, factories, farms and forest fires. ${ }^{3}$ The main cause of this

${ }^{1}$ Luca Tacconi, Kebakaran Hutan di Indonesia: Penyebab, Biaya dan Implikasi Kebijakan, CIFOR, 2003, 5-10.

'Lindsay Knight, World Disaster Report 2009, Focus on Early Warning, Early Action, IFRCS, 2009, 162-169.

${ }^{3}$ www.wikipedia.org 
imbalance is the worldview that sees human being as the centre of the life, so they can exploit the land and its resources without the attention to the balance of the environment and the continuation of the next generation. ${ }^{4}$ This worldview will lead to the destruction of the earth and harm human life. Ziaudin sardar mentioned that the root of the environmental crisis is the people's faith and system value that create lifestyle and idea of the people. ${ }^{5}$

Lynn White Jr. also agrees with this statement and said that "What human action towards the environment derives from his worldview in the relationship between man and the universe, and therefore their thought is influenced by their belief system in the world, means it is influenced by their religion"6. He said that Christianity reinforce this case and place the human being right over the universe and that the universe was created for the human need. ${ }^{7}$ This is the face of harsh criticism because religion is very important cause in the occurrence of exploitation in the world and it plays a very significant role and major impact in guiding human behaviour toward himself and his environment because ethical principles in religion bound to do so.

Many people said that Islam is equal to other religion especially Christianity in this case especially if we look at the following verses (alJāthiyah: 12-13, al-Zukhruf: 13, Luqmān: 20 and Ḥaj: 65). So regarding this issue it is very important to answer the position of Islam especially the Quranic teaching toward environment? What is actually the Quran teaches about man's relationship to the environment? And what are human responsibilities for the environment in the light of the Quran?

${ }^{4}$ Erlangga Husada, Kajian Islam Kontemporer, Jakarta: UIN Jakarta Press, 2007, 126.

5Ziauddin Sardar, Islamic Futures, New York: Mensell Publishing Limited, 1985, 218.

${ }^{6}$ Richard C. Foltz, Islam and Ecology: A Bestowed Trust, Cambridge: Harvard University Press, 2003, xvi. 


\section{The concept of human in the Quran}

The Quran has different words that represent human being which is has different meaning and stressing. The Quran repetitively used insān, bashar and bani $\bar{A} d a m$ and dhurriyat $\bar{A} d a m$ with its derivation, we will elaborate the concepts as follows.

\section{Insān}

Ibnu Faris said that insān derived from (alif, nun, sin) and has several meanings. The first meaning is the emergence thing that can be sense, it is the opposite of hidden (jinn), something that eye can see and mind could think about, while the second meaning is the opposite of savagery or barbarism. ${ }^{8}$ And its derivative found in the Quran is unāsun, أناسي , mustanasin, insiyyan, ānas, ānastum, ānasta, tasta'nisu, ins, insān dan nās. While Al Isfahani said that human is a creature that could not stand without other human beings, they need each other; this has been said that human is a civilized creature in his nature. ${ }^{9}$

Ibnu Mandzur in Lisān al-'Arab said the other meaning of "insān" is forgetfulness, like what has been narrated from Ibn Abbas, he said that human called "insān" because they had been entrusted but then he forgot, while Abu Mansour said that "insān" originally come from "insiyyan" that means forgetfulness. ${ }^{10}$ This perspective was confirmed by the Quran in Tạāā verse 115 .

\footnotetext{
'Lynn White Jr., "The Root of Our Ecological Crisis", Journal of The American Scientific Affiliation, http://www.asa3.org/ASA/PSCF/1969/JASA6-69White.html.

${ }^{8}$ Ibnu Faris, Mu'jam Maqāyis al-Lughah, Kairo: Maktabah Alkhabkhi, 1402 H/1981 M, vol. 3, 145.

${ }^{9} \mathrm{Al}$ Isfahani, Mu'jam Mufradāt li Alfāz al-Qurānn, Beirut: Dār al-Kutub al-'Ilmiyyah, $1420 \mathrm{H}$ / 2004 M, 36.

10Ibnu Mandzur, Lisān al-'Arab, Beirut: Dār al-Ṣadr, 1410 H/1990 M, 12.
} 
"Ins" is mentioned 18 times in 9 places $^{11}$ and was followed by a word "jinn" and "jann" in some quranic verses to indicate the difference of the basis. "Insān" is emergence creature and can be sensed while Genie is hidden, it does not appear. ${ }^{12}$

While "insān" mentioned 65 times in 43 surahs $^{13}$ it came with "alif wa al-lām" in 64 times and came without the alif and the lam once in alIsrā' ayat 13 to indicate human as creature that has responsibility. ${ }^{14}$ The word "insān" in the Quran also indicate the basic characteristics of human such as greedy, thankful, disbelief, rush, injustice and not thankful, desperate, and weak. ${ }^{15}$ The word "insān" also used to explain the process of the creation of human being which consists of material earth such as mud, dirt and the like. ${ }^{16}$

Aisha bint Syathi said that the previous verses talking about humanity that elevate human being to the degree that make them qualify for succession (khiläfah) in the world and to accept responsibility and mandate, because human has been favoured with science, intellectuality, geniality, and the ability to distinguish values that make human capable of doing good and bad. ${ }^{17}$ From the verses above we can conclude that "insān" define relevant aspects of his qualities and responsibilities.

The other verses indicate the special quality of human being that distinguish them from other creatures. that is knowledge just like indicated by the repetition of the word "insān" in al- 'Alaq verse 2, 3 and 6.

\footnotetext{
${ }^{11}$ Mohammad Fuad Abdul al-Baqi, Mu'jam Mufahras li Alfāz al-Qur'ān, Cairo: Dār Kutub Mișriyyah, 1964, vol. 3, 93

${ }^{12}$ Ibnu Faris, Mu'jam Maqāyis al-Lughah, Cairo: Maktabah al-Khabkhï, 1402 H/1981 M, vol. 3, 422.

${ }^{13}$ Mohammad Fuad Abdul al-Baqi, Mu'jam Mufahras li Alfāz al-Qur'ān..., 93-94.

${ }^{14}$ Look at al-Ahāāb: 72 and al-Qiyāmah: 13.

${ }^{15}$ These can be found in the folowing verses: al-Isrā': 100, 67, 11; Ibrāhim: 34, Fușșilat: 4; alNisā': 28.

${ }^{16}$ Șaffāt: 11 and Âli 'Imrān: 59; Ṭāhā: 55; al-Sajdah: 7.

${ }^{17}$ Binti Syathi, Al-Qur'ān wa Qađ̣aya al-Insān, Kairo, Dār al-Ma'ārif, NA, 19-20.
} 
A more comprehensive definition come from Mahmoud Ekad who said that human being is a living organism which has distinctions from the rest of the creatures with knowledge and free will so they have specific assignment and responsibility. ${ }^{18}$

\section{Al-Nās}

The word "al-nās" mentioned in the Quran is the plural form of "insān". The word "al-nās" is used to explain the position of human as social creature. Bintu Syathi said that "al-nās" explains the human relation as one species in absolute form ${ }^{19}$ and then make human being into nations and tribes so that human form social life and learn about each other, and also indicates that the joy and happiness will not exist unless if they build relations among others. ${ }^{20}$

The word "al-nās" also indicates that the resources in the world are created for human being so they can use it to fulfil their basic needs. Just like water that human can drink, and creation of the heavens and the earth, and the alternation of night and day, and astronomy that take place in the sea including that all are for the benefit of human being. The word "al-nās" also used to explain human function in cattle watering and something like that. ${ }^{21}$ These verses show that "al-nās" was mentioned to explain the position of human being as social creature that relate to and need to each other, as well as to demonstrate human activities on earth.

18Mahmoud Akkad, al-Islām wa al-Insān, Dār Fușșilat li al-Dirāsat wa al-Tarjamah wa al-Nashr, 1999 M/1419 H, vol. 2, 30.

${ }^{19}$ Binti Syathi, Al-Qur'àn wa Qađ̣aya al-Insān..., 17.

${ }^{20} \mathrm{Al}$-Hujurat: 13 and Āli 'Imrān: 112.

${ }^{21} \mathrm{Al}-$ Baqarah: 164 and al-Qașaș: 23. 


\section{Banī $\bar{A} d a m$ and dhurriyat $\bar{A} d a m$}

The word "banק" is originally derived from "banūn" that means something which is generated from thing, just like son of man or others, ${ }^{22}$ while the word "dhurriyyat" means descent. ${ }^{23}$ The meaning of banū $\bar{A} d a m$ or dhurriyyat $\bar{A} d a m$ refer to human being because it is added to the word " $\bar{A} d a m^{\prime}$ ", and this indicates that all people have the same origin that is $\overline{A d a m}$ the first human in the earth, as mentioned in the story of $\bar{A} d a m$ (al Baqarah: 34). The word "banū $\bar{A} d a m^{\prime}$ refers to the blood relation among people, while the word "dhurriyyat $\bar{A} d a m^{\prime}$ related to various nations, tribes, languages and colours. ${ }^{24}$

There are three verses in the Quran which mention "bani A $\overline{d a m}$ " in relation with dress code, body maintaining and cover genitals (aurat), ${ }^{25}$ and other three verses related to faith and the explanation of human enemy, the devil, ${ }^{26}$ and single verse explains the advantages of human being in land and sea. ${ }^{27}$ These verses confirm that human being has advantages and special capacity in comparation to others creatures.

\section{Bashar}

"Bashar" consist of $(b, s h, r)$ that means the emergence thing with a good appearance and beauty, while Abu Zaid said that human being was stated using word "bashar" as the appearance of skin and not covered by hair unlike animals that has wool or hair. ${ }^{28}$

\footnotetext{
${ }^{22}$ Ibnu Faris, Mu'jam Maqāyis al-Lughah, vol. 3, 303.

23Jamā'ah min Kibār al-Lughawiyyīn al-'Arab, al-Mu'jam al-'Arabï al-Asasï, al-Munaẓzamah al'Arabiyyah li Tarbiyah wa Thaqafah wa al-'Ulūm, 1424/2003, 479.

${ }^{24}$ Al-Rūm: 22; al-Hujurāt: 13.

${ }^{25}$ Al-A'rāf: $26,27,31$.

${ }^{26}$ Al-A'rāf: 35, 172; Yāsinn: 60.

${ }^{27} \mathrm{Al}$-Isrā': 70.

${ }^{28}$ Ibnu Faris, Mu'jam Maqāyis al-Lughah..., vol. 3, 251.
} 
The word "bashar" mentioned 36 times in 28 verses, $^{29}$ with 25 of them to denote on the basic human need like eating or drinking and touching, and twelve the remaining verses related to humanitarian aspect of the prophets and apostles like in al-Kahf verse $110 .{ }^{30}$ And the word "bashar" also refers to relationship between Prophet with infidels who reject the Prophet hood of Muhammad because they thought that the Prophet as a man like other $\operatorname{man}^{31}$, as stated in Ibrāhim 10-11 and in Hūd 27. While other verses explain the infidelity of the People of Noah who disclaim the calling of the Prophet to worship God the almighty ${ }^{32}$ as well as the People of Tsamud who denied the prophecy in favour of Shaleh (al-Shuarā': 154).

The word "bashar" also indicates the stage of human development from children until adulthood like mentioned in al-Rūm 20. Quraish Shihab said that "bashar" shows the maturity and the ability to have sexual relationship and thus related to the spread of descendant (تنتشرون).33 This also means that sexual relationship does not happen until after puberty and adulthood. So no wonder in the case of Maryam used word "bashar" related to the her pregnancy and no man even touch her, as contained in the following verse [Äli- 'Imrān: 47]. ${ }^{34}$

The derivation of "bashar" is "bāsyara" means sexual practitioner as found in al-Baqarah verse 187. This indicates that the word "bashara" show maturity and carry responsibility, and the word 'bashar" also talks

\footnotetext{
${ }^{29}$ Mohammad Fuad Abdul al-Baqi, Mu'jam Mufahras li Alfāz al-Qur'ān..., 120-121.

${ }^{30}$ Wahbah Bin Musthafa al-Zuhaily, al-Tafsir al-Munir fi al-'Aqidah wa al-Shari'ah wa al-Manhaj, Damascus: Dār al-Fikr al-Mu'āshirah, 1418, vol. 2, 43.

${ }^{31}$ Wahbah Bin Musthafa al-Zuhaily, al-Tafsir al-Wasiț li al-Zuhayli, Damascus: Dār al-Fikr, 1422, vol. 1.

${ }^{32}$ Wahbah Bin Musthafa al-Zuhaily, al-Tafsir al-Munir i..., vol. 2, 54.

${ }^{33}$ M. Qurasih Shihab, Tafsir Al-Mishbah: Pesan, Kesan dan Keserasian al-Qur'an, Jakarta: Lentera Hati 2007 M / 1428 H, vol. 2, 22.

${ }^{34}$ Muhammad Rashid Ridha, Tafsir al-Qur'ān al-Hakim, Cairo: Al-Hay'ah al-Mișriyyah al-'Āmmah li al-Kitāb Sunnat al-Nashr, 1990, 253.
} 
about khilafah in al-Hijr verse 28.35 Aisha bint Sathi said that "bashar" indicates the human material activity like eating food and walk in the markets, and it is to demonstrate the human side of the prophet. ${ }^{36}$

From this description, we find that word "bashar" explain human being on the side of humanity; "bashar" indicates that the apostle as human beings eats food, walks in the markets, and does other physical activities.

From this section we can see that the Quran has a very deep perspective in explaining human being from various aspects. The Quran also discuss the advantages and special ability of human being compares to others creatures. The Quran not only talks about human being on its physical aspects but also social and cultural.

\section{Human in the Quran: assignment and responsibility}

The Human mission will show his relationship with God and with man and the universe. There are two assignments of Human beings in Quran as khalifah and 'abdullāh.

\section{Human as slave of God ('abdullah)}

The famous verse on human assignment is al-Dhāriyāt: 56. The "lam" in the verse is added to show the purpose and the objective so it indicates that human being has only primary purpose that is to worship the God alone. ${ }^{37}$ And the verse also uses "ma" and "Illa" which its function is to limit, so the meaning of the verse is to command them to worship not because God need them to worship but it is the main purpose of the creation of human being.

${ }^{35}$ Wahbah Bin Musthafa al-Zuhaily, al-Tafsir al-Munir i..., vol. 2, 32.

${ }^{36}$ Binti Syathi, al-Qur'ān wa Qađ̣āya al-Insān, Cairo: Dār al-Ma'ārif, 15.

${ }^{37}$ Al-Zarkasyi, al-Burhān fi 'Ulum al-Qur'ān, Cairo: Dār al-Iḥyā' al-Kutub al- 'Arabiyyah, 346. 
Worship or "ibādah" originates from "'abada, ya'budu, 'ibādatan" means soft and humiliation, and the other meaning is severity and thicken. Ibnu Mandzur said that the term "'abdun" means slavery, submission and ' grovelling. ${ }^{38}$ While Raghib al-Asfahani differentiates between "'ibādah" and "'ubūdiyyah". He said that "'ubūdiyyah" to show grovelling while "'ibādah" means the ultimate submission to Allah the almighty. ${ }^{39}$ If we look at these perspectives, the meaning of "ibādah" and "ubūdiyyah" have the same around grovelling, submission and obedience.

Here is some definition of "'ibādah' from some scholars. Al-Qassimi said that "ibādah" is the worship to the almighty based on his command delivered by his Messenger, what there will be no good and no happiness in here and hereafter except with it. ${ }^{40}$ While al-Wahidi defines "ibādah" as obedience and worship, and "'ibādah" is human acts that indicate obedience to commands and laws and the recognition of submission to it. ${ }^{41}$ Ibn Kathir said that the meaning of "ibādah" is every work to collect the love and a full surrender to God and a fear of the Lord's rejection. ${ }^{42}$ Mohamed Rashid Ridho said that "ibādah" is self vigilant to the almighty what he does not know its origin and what it really is. ${ }^{43}$ But Mahmoud Shaltout he said that worship is uncountable vigilant to the king and this vigilant is the spirit of worship which is not valid only with it. ${ }^{44}$

38Ibnu Mandzur, Lisān al-'Arab, Beirut: Dār al-Ṣadr, 1410 H/1990 M, vol. 1, 2774.

${ }^{39}$ Al-Isfahani, Mufradāt Alfāz al-Qur'ān, Beirut: Dār al-Shamiyyah, 1992, 319. See also alIsfahani, al-Mufradāt li Gharīb al-Qur'ān, Beirut: Dār al-Ma'rifāt), 319.

${ }^{40} \mathrm{Al}$-Qasimi, Maḥāsin al-Ta'will, Cairo: Dār al-Iḥyā' al-Kutub al-'Arabiyyah, vol. 15, 5538.

${ }^{41}$ Al-Wahidi, Asbāb al-Nuzül, Beirut: Dār al-Fikr, 1994, 3.

"22Ibnu Katsir, Tafsir Ibnu Kathïr, Beirut: Dār al-Fikr, 1986, vol. 1, 25.

${ }^{43}$ Muhammad Rashid Ridha, Tafsir al-Manār, Cairo: Cairo Library, 1960), 87.

44Mohammed Shaltout, Tafsir al-Qur'ān al-Karìm, Beirut: Dār al-Qalam, 1965), 29. 
From above definitions we can understand that scholars interpret worship is not only about action in complying to orders, but also inference of obedience and comprehensive submission and surrender to God, and it is not meant that God needs these all. So we must understand that God has purposes in all His actions. Worship is an essential purpose in creating human being and God created people to give human being reward but in the same time God does not need anything from human. ${ }^{45}$

If obedience is an essential part of worship, but actually in fact, why there are a lot of people do not worship the God? Quraish Shihab quoted Thabathabi said that human being has been created by Allah in order to worship Him and they also have freedom of choice in worship..$^{46} \mathrm{Al}$-Sinqaiti said that worship is the examination for people to see which one is best pursuant. ${ }^{47} \mathrm{Al}$-Isfahani said that there are two kind of worship; first default worship with no choice and this for all include human being, animals, plants and every object in the world as stated in the verse al- Ra'd verse 13. While the second is worship with choice for those who has reason like mentioned in al-Baqarah verse $21 .{ }^{48}$

\section{Human as successor of God on earth (khalifa)}

Al-Damgani said that khalifa ${ }^{49}$ in the Quran has three meanings, those are prophet, successor of the foregone and inhabitant. ${ }^{50}$ While al-

${ }^{45}$ M. Qurasih Shihab, Tafsir al-Mishbah..., vol. 13, 358.

${ }^{46}$ M. Qurasih Shihab, Tafsir al-Mishbah..., jilid 13, 358.

${ }^{47}$ Al-Sinqiti, Adwā' al-Bayā'n fi Iydah al-Qur'ā'n bi al-Qur'ā'n, Beirut: Dār al-Fikr, 1995), vol. $8,445$.

${ }^{48} \mathrm{Al}-\mathrm{Isfahani}$, al-Mufradā't li Gharì'b al-Qur'ā'n, Beirut: Dār al-Ma'rifat, 319.

${ }^{49}$ The word khalifa can be found in al Baqarah: 30; Șad: 26 and in plural form khalä'if (heirs) found in al-An'ām: 165; Yūnus: 14, 73; Fāțir: 39; khulafā'' has been mentioned three times in alAn'ām: 69; Fātịi: 74 and al-Naml: 62.

${ }^{50} \mathrm{Abi}$ Abdullah Al-Hussein Bin Mohammed Al-Damghani, al-Wujūh wa al-Naẓā'’ir, Beirut: Dār Kutub al-'Ilmiyyah, 203. 
Isfahani said that khalifa is the succession of others either because he has gone away, or to his death, or by his inability, and or to honour one who replaced. ${ }^{51}$ Quraish Shihab interpreted that in the previous verses (al-Baqarah: 30 and Sad: 26) the word khalifa is used for those who has power to manage the region or has a wide or limited political force, he refers this conclusion to the succession of David who rules Palestine (1000 - 947 BC), and Adam which give succession to the world in the first era of human being. ${ }^{52}$ And that each successor has the possibility to commit errors and mistakes because of his carnal desire, and therefore God warned Ādam and David in Ṭāhā: 16 and Șad: 26.

Mohammed Baqir al-Sadr said in his book al-Sunan al-Tarikhiyyah fi al-Qur'ann, as quoted by Quraish Shihab that the khalifa consist of three elements that related to each other and those are human being as successor and the universe in which represented by al-Ard (earth) and the relationship between people and the universe, include relationship between human and human with the entire universe such as the environment and so on, and the fourth element is the God who has subjugated the heavens and the earth to human being, and therefore human have to care about and comply the orders from Allah who give him succession. ${ }^{53}$

This also means that human responsibility as khalifa is to establish the rule of God in the land and to manage resources in the universe which includes people, animals, plants, and all creatures. Moreover, the relationship between people and people or the universe is neither relationship between conqueror and conquered and nor relationship between master and slave, but it is an assembly relationship in obedience

\footnotetext{
${ }^{51}$ Al-Isfahani, Mufradāt Alfāz al-Qur'ān, Beirut: Dār al-Shamiyyah, 1992, 155-156.

${ }^{52}$ Dikutip dari M Quraish Shihab, Membumikan al-Quran: Fungsi dan Peran Wahyu dalam Kehidupan Masyarakat, Bandung: Mizan 1419 H/1998 M, 158.

${ }^{53}$ Dikutip dari M Quraish Shihab, Membumikan al-Quran..., 158.
} 
and submission to Allah as its creatures. And that, even if everything has been subjugated for humans, it is not because of his strength but doe to He forced them for human (Ibrāhim: 32; al-Zukhruf: 13).

Therefore succession (khiläfa) intends to build interaction between human and human, between human and the world or the universe that suitable with God command as in al-Zukhruf: 32. It does not mean that sukhriya in this verse means coercion and not subjugation, but relationship of obedience in the sense that everything has place depending on the ability and subscription. God makes someone rich and others poor and this is does not mean that He stressed on subjugation of each other, but mutual help among them. The rich may help the poor with their money, and the poor may the rich help with their work, each of them has their own function. ${ }^{54}$

The important point of this concept is that the relationship between the creatures is based on integration and solidarity and coexistence. This is the basic principle of the relationship between the very creatures in the world that became the morality of religion. We would acknowledge the principle, "that everyone is allowed to do anything as long as does not violate another right", but the principle also stressed on mutual help among them. ${ }^{55}$

This is what God has guided us, and we have to conduct in line with these guidelines nad God will bless us and gave a lot of good (Jinn: 16). Quraish Shihab said that the character which khalifa has to do with is justice (al-Baqarah: 124) and (Șad: 26). Injustice is the opposite of justice and its meaning is to rule with right, this is the very important character of khalifa. ${ }^{56}$ And also stated that the imam or

\footnotetext{
${ }^{54}$ Al-Baghawi, Ma'álimu al-Tanzïl, Riyadh: Dār Ṭayyibah, 1409 H, vol. 7, 211-212.

${ }^{55}$ M. Quraish Shihab, Membumikan al-Quran..., 160.

56M. Quraish Shihab, Membumikan al-Quran..., 164.
} 
caliph must have ethics and qualities as mentioned in the al-Anbiyā': 73) and al-Sajdah: 24.

From this section we can conclude that the Caliph has the authority to manage the state both in large or small scale. There is an important relationship between the caliph and another creature, that the caliph must be fair and set an example for others. There is a verse explained that the caliph (al-Hajj: 41) has a strong relationship with the Creator through prayer, paying the zakat shows that he has a good relationship with other creatures, including animals and plants in the world, and ma'rüf is known as convention on all the good in the religion, culture, habit and the opposite of evil. The khalifa is those who has given succession by the God to manage this earth and must establish a society that has a good relationship with God, and make integration and take into account the interdependence between religion, reason, and culture.

\section{The concept of the environment in Quran}

The Quran talks about the environment in various words and expressions. Mujiono Abdillah said that the Quran expressed the environment using these words: al-'allamin (the universe), al-samā' (sky), al-ard (earth) and $a$-bi'ah (environment)..$^{57}$

The Quran mentioned the word al-ālamin 46 times. In some places it means all objects in the universe as in al-Fătihah verse 2: "Praise be to Allah, the Lord of the universe." The word 'alamin is plural form of 'âlam that means world, species and creatures. ${ }^{58}$ The word also means all things, and it also used to a collection of distinct group like the

${ }^{57}$ Mujiono Abdillah, Agama Ramah Lingkungan Perspektif al-Qur'an, Jakarta: Paramadina, 2001, 33-34.

58Ibnu Mandzur, Lisān al-'Arab..., vol. 1, 216. 
human world, and the world of the animal and plant etc. As in Âli'Imrān: 37, this verse indicates that the 'âlamin is common covered every world whether rational or non-rational.

In some places the word 'âlamin was specified for human being or creatures that have logic (al-A'rāf: 80). And the main reason that the word 'àlamin specifies to human being is a presumption which refers to the character in the nature of people like guidance, warning, geniality, heart and messengers. ${ }^{59}$

While the word al-samā' means the stars and the planets (alBaqarah: 22). Ahmad Baiquni explained that al-samā' with stars, planets and space. ${ }^{60}$ The al-samā' also means the air (al-Nahl: 79 and Furqān: 61). ${ }^{61} \mathrm{Al}$-samā' means space, although mentioned in the Quran variety of style, but the meaning is space, the universe and the world. ${ }^{62}$

The Quran expressed environment with the term al-ard (land) as shown in verse 164 of Surah al-Baqarah. If we look at verse 24 of Surat al-A'rāf verse 24 , the environment means a place of stability and heirlooms. If we look at the previous verses and their meanings the word al-ard has the close meaning with environment. ${ }^{63}$

The other word that is consistent with the environment is al-bi'ah (Yūsuf: 56; al-Naḥl: 41 and al-Ankabūt: 48). From these verses we can see that the environment is the place where humans live and enjoy their life.

From previous section we can see that the Quran defines the environment in broadly meanings because they include the planets and the

\footnotetext{
${ }^{59}$ Mujiono Abdillah, Agama Ramah Lingkungan..., 32.

${ }^{60}$ Achmad Baiquni, al-Qur'an, Ilmu Pengetahuan dan Teknologi, Yogyakarta: Dana Bhakti Wakaf, 1993, 29.

${ }^{61}$ Mujiono Abdillah, Agama Ramah Lingkungan..., 43-45.

${ }^{62}$ Mujiono Abdillah, Agama Ramah Lingkungan..., 43-45.

63Mujiono Abdillah, Agama Ramah Lingkungan..., 46-47.
} 
skies and space exterior. The environment is not only covering humans' environment, but it also include all species from the environment, such as earth and outer space and even the heavens.

\section{Environmental problems}

\section{Pollution}

Pollution, as defined by some of the specialized scientific bodies, is the presence of pollutants such as chemical agents, radiation or noise, with quantities or qualities that harmful to human life, plant and animal, property or spoils to the urban environment. ${ }^{64}$ The pollution is a quantitative or qualitative change in the components of systems in the living and non-living environment that are unable to be absorbed by the environment without disturbing its balance. ${ }^{65}$

Quantitative change may increase the proportion of some components of natural environment such as carbon dioxide from the usual rate as a result of the enormous fires landing that still occur in forest areas and herbs. And it may be by adding a small amount of a substance in a sensitive site, as the case of leak oil to the sea as a result of corruption in the oil tanker accidents or etc., and produces a quantitative change of adding materials can be toxic or even fatal for its natural like mercury and carbon oxides and radioactive materials. ${ }^{66}$

And qualitative change is caused by adding a strange industrial vehicles on systems of natural environment, where it had never was in their role and chains where accumulate in the air or water, food or soil,

${ }^{64} \mathrm{Abdul}$ Rahman Jirah, al-Islām wa al-Bi'ah, Dār al-Salām li al-Ṭibā'ah wa al-Nashr wa al-Tawzi' wa al-Tarjamah, 1420/2000, 71.

${ }^{65}$ Rashid al-Hamd and Mohammed Saeed Sabarini, 'Alam Ma'rifah No. 22: al-Bi'ah wa Mushkilatihā, Kuwait: al-Majlis al-Awatthanī li al-Thaqafah wa al-Qanūn wa al-Adab, 1979, 120.

${ }^{66}$ Rashid al-Hamd and Mohammed Saeed Sabarini, 'Ālam Ma'rifah..., 121. 
and the most prominent examples of these pesticides agricultural pests and herbicides. ${ }^{67}$

Pollution in this concept is the existence of any material or energy that were not in their proper place and time and quantitaty. Water is considered as contaminated if it added to the amount of soil and replace the air, and when salts accumulate in the agricultural land due to inadequate drainage systems are considered pollutants, and sounds when increasingly tightening its a certain extent pollutants harassed human.

\section{Depletion of resources}

The environment is the wealth of resources available for human in the world. The resources of were divided into renewable and non-renewable. Renewable resource is a renewable natural resource, which are not self-depletion and can be used continuously. But we have to exploit it in mild and good manner away from extravagance, such as water, air and soil, animals and plants. And the non-renewable resource is the existing resources of the environment in the form of fixed amount and it has not been compensated, they are coal, oil, natural gas and minerals radioactive. ${ }^{68}$

Resource depletion is a reduction of valued supplier or a failure to perform its normal role in life-cycle and food chain. The problem is not only because the reduction value or the scarcity but it will effect to the balance of the ecosystem as a whole. ${ }^{69}$ Depletion of natural resources is significant problem of human life, because if the natural resources

\footnotetext{
${ }^{67}$ Rashid al-Hamd and Mohammed Saeed Sabarini, 'Alam Ma'rifah ..., 121.

${ }^{68}$ www.wikipedia.org/wiki/natural_resource

${ }^{69} \mathrm{Hamad}$ Salamah Mohammed, Muqtarah Istirätijiyyah li Idārah al-Anhyițāt al-Ta'diniyyah bi al-Muhammiyah al-Ṭabīilyah, al-Idārah al-Markaziyyah li Himāyah al-Ṭabīiyyah Juhāz Shu'ūn alBi'ah, Wuzārah al-Dawlah li Shu'ūn al-Bi'ah.
} 
depleted, human could not fulfil his need and in addition it also will effect ecological balance.

The reasons for the depletion of resources is the misuse and extravagant exploitation that exceed the limit or neglected the capacity leading to a condition of disrepair or damages in the earth and finally harm the environment. ${ }^{70}$ The other reason is the increasing of population the earth's and the progress of industrial technology which leads to accelerate the depletion of resources.

\section{Extinction of species}

Extinction is a decrease of the number of species constantly with no compensation or replacement that lead to total disappearance. It will cause an empty space in the life cycle or the ecosystem that will disrupt ecological balance and the final was so kind irreplaceable. ${ }^{71}$ In biology and ecology, extinction is the end of an organism or of a group of organisms (taxon), normally a species. The moment of extinction is generally considered to be the death of the last individual of the species, although the capacity to breed and recover may lost before this point. ${ }^{72}$

And extinction occurs both naturally or causally. Natural extinction is a natural event in the evolution where members of one type disappear and has been replaced by new types in accordance to the natural selection. The species that can adapt to the environmental condition will remain and take benefit from its resources, while other species that cannot adapt will be vanished. In the other side, causal extinction could be happened because of human interventions either directly or indi-

\footnotetext{
70Yusuf al-Qardhawi, Ri'āyah al-Bi'ah fi Sharíah Islām, Dār al-Shuruq, 2001), vol. 1, 199.

${ }^{71}$ Wuzārah al-Tarbiyyah wa al-Ta'ilim, Istinzāî al-Mawārid al-Tabīíiyyah, Sultanah Oman, 2008, 11.

${ }^{72} \mathrm{http}: / /$ en.wikipedia.org/wiki/Extinction
} 
rectly. For example of direct cause is human wars or hunting using modern machinery to kill certain species and then the species is vanished. The example of indirect cause is human activity in burning forests or removing the plant cover, pesticides or pollution.

Extinction has a great and significant impact to the lives because the stability of the biological balance in any environmental system is associated with multiple species that interact each other. Every species has specific role and function in the food chain, and also in the integration with other species to trigger different interactions in the ecosystem. ${ }^{73}$ If a species extinct, its role will stops and will affect the role of other species. So extinction has a negative effect in biological balance and disturb environment.

\section{Global warming}

Global warming is the phenomenon of the high temperature in the environment as a result of change in distribution of thermal energy from and to the environment. The global warming is the phenomenon of the increasing world temperature from the normal rate. According to the International Panel on Climate Change, majority of the increasing rate of global temperature since the mid-twentieth century largely due to the enlarging greenhouse gas effect caused by the activities carried by humans. ${ }^{74}$ The main causes is the burning of fossil fuels such as coal, oil and natural gas in factories, cars and forests and farms combustion which sends carbon dioxide and other gases known as greenhouse gases into the atmosphere.

\footnotetext{
${ }^{73}$ Wuzārah al-Tarbiyyah wa al-Ta'Iim, Istinzaāf al-Mawārid al-Tabīíyyah, Sultanah Oman, 2008, 14.

${ }^{74}$ IPCC, Summary for Policymakers in Climate Change 2008: The Physical Science Basis, Cambridge: Cambridge University Press, 2007), 2 -3.
} 
Global warming is causing negative impact to the continuity of the earth and leading to the occurrence of extreme climate change that encourages hurricanes, storms and floods. It also causes changing pattern of rainfall that could not be predicted anymore and even cause floods in one place but drought elsewhere, and the cyclone of new tropical storms will appear much stronger and longer. ${ }^{75}$ In last ten years, there have been 1.695 floods and 1.062 and 272 droughts and 204 extreme temperatures. The global warming also causes the spread of diseases from tropical regions to new areas because the extreme increase of mosquitoes. There are 16 plagues has occurred in last ten years. ${ }^{76}$

Factors in the environmental crisis

The constant population growth will lead problem in food provision and other requirements for human life in the following decades. Extreme growth in population cause major problems in the environment and related that to any other environmental problem. ${ }^{77}$

The feature of contemporary society is acceleration of the changes brought by scientific and technological revolution in environment. The magnitude and some effects with these two revolutions are two problems that are environmental pollution and depletion of resources. Pollution problem is taken a lot of attention in view of its negative effects to the quality of human life. Pollutants come to human body through the air they breathe, water they drink, food they eat and noises they hear. While depletion of renewable and non-renewable resources are the

\footnotetext{
${ }^{75}$ Agus R dan Rudi, Global Warming Mengancam Keselamatan Planet Bumi!!!, www. hiduplebihmulia.wordpress.com.

${ }^{76}$ Lindsay Knight, World Disaster report 2009, Focus on Early Warning, Early Action, IFRCS, 2009, 163-166.

${ }^{77}$ Rashid al-Hamd and Mohammed Saeed Sabarini, 'Alam Ma'rifah ..., 111.
} 
issues that threatens the lives of future generations. ${ }^{78}$

A large complex system of environment consists of a set of elements (living and non-living) which interact and influence each other, governed by the fundamental relations to reserve its complexity and control its balance. The environment consists of a set of smaller systems that being a component in chains. And natural cycles of reservation also have role to reserve the complexity and its balance. And ecosystems have been and are still changes because of human actions (the steady increase in population, pollution and resource depletion) that could not be estimated which led to overwhelm or degradation. ${ }^{79}$

Human intervention has affected to the natural balance of environment and made systemic problems globally such as climate change and other problems that happened in certain parts of the earth such as deforestation in some areas, and the extinction of some wild animals, marine ecosystems and other specific part like deserts.

\section{Human and the environment in the Quran}

In the previous section we have known the concept of human being and the environment in the light of the Quran. God had made human being as his successor in the world (al-Baqarah: 30) with two exclusive advantages, those are the mind that makes human capable to have unlimited knowledge and ability and also gaves them free will so they be able to choose and make decisions on earth (al-Baqarah: 31). With these two advantages, God gave him exclusive do's and don'ts, responsibilities and rights and then make his life as choices to examine at his best pursuant (Hūd: 7, al- Shams: 8). Based on these perspec-

\footnotetext{
${ }^{78}$ Rashid al-Hamd and Mohammed Saeed Sabarini, 'Ālam Ma'rifah ..., 111.

${ }^{79}$ Rashid al-Hamd and Mohammed Saeed Sabarini, 'Alam Ma'rifah ..., 111.
} 
tives, these are responsibilities of human being towards the environment in the light of the Quran:

\section{Contemplation, reflection and consideration to the environment}

The first message that people aware of the Quran is command to think and reflect on the universe to discover its secrets. This message came from the first revelation come down to the holy Prophet, when he went into seclusion in Hira cave and receive the first revelation of al'Alaq $1-5 .{ }^{80}$ Ibn Katsir said that the verse alerts that science and learning is the strength that makes human being better than angels. ${ }^{81}$ Ibrahim Ozdemir said that the verse is not only a command to read, but also to learn about the matters of the universe, because the Prophet is illiterate does not reads and writes, but God gave him mind and insight by which human can reflect on things. ${ }^{82}$ The other verse related to the command of thinking the universe are including Yūnus: 101, al-Ghāshiyyah: 17-21, al-Baqarah: 164 and Qāf: 6-10.

These verses talk about the universe, which refers to the environment and its elements particularly the natural environment. God urged human being to think about, consider and manage the universe and the environment in which people live. Al-Isfahani said it includes stirring sight and insight to understand one thing and to see it, meditate and examinate, it also means the knowledge that gained after the contemplation or vision. To think and to meditate the skies and the earth leads to the knowledge of the Creator and knowledge of its signs and miracles. ${ }^{83}$

${ }^{80}$ Ibnu Katsir, Tafsir al-Qur'ān al-Karïm..., vol. 1, 8.

${ }^{81}$ Ibnu Katsir, Tafsir al-Qur'ān al-Karïm..., vol. 14, 398.

${ }^{82}$ Ibrahim Ozdemir, "Toward and Understanding of nvironmental Ethics from Quranic Perspective", in Islam and Ecology a Bestowed Trust, Harvard: Harvard University Press, 2003, 7.

${ }^{83} \mathrm{Al}$ Isfahani, al-Mufradāt li Gharīb al-Qur'ān..., 497. 
Commenting on Qāf: 6, Ahmad Fuad Pasha said that to think about the universe is the source of pleasures in the world and happiness in the hereafter, and anyone who do so will have more faith, guidance and insights from God. But it does not mean that knowledge just seen with naked eye, or perceived by senses, but it is also to think with the scientific methods that will lead to understanding the universe. ${ }^{84}$

There are reasons why God ask human to think of the universe. Firstly, God has given human mind and insight, if we give a close attention to verses in the Quran, the challenge to think about is only addressed to those who have mind, feeling and that is human being (al-A'rāf: 179 and Yūsuf 10: ). Secondly, to reflect on the environment will keep human being close to God, so they will understand and feel the power of God the almighty. Once the unbelievers complain about the presence of God then they are challenged to think and forethought the creation of the skies and earth (Āli 'Imrān: 190-191). Fakhru Razi said that to reflect on the creation of the heavens and the earth will lead to perfect faith, so if $d h i k r$ is the form of worship of the tongue, to commit a prayer is form of worship of the limbs, so to think is the form of worship of mind, heart and spirit. ${ }^{85}$ Thirdly, Allah has created the universe for the benefit of human being so they can use it and exploit it in good manner for the benefit of all creatures as mentioned in Ibrāhim: 32-34. In order to be able to do so, human being should know and understand how the environment is running and relationship that happen in the universe. ${ }^{86}$

${ }^{84} \mathrm{Jamal}$ Mohamed Mohamed al-Hanidi, Tarbiyah 'Ulamā' al-Tabíiyyah wa al-Kawniyyāt alMuslimin fi al-Qurūn al-Khamsah al-Ūlā min al-Hijrah, Dār al-Wafā', 1421 H/2001 M, vol. 1, 84.

${ }^{85}$ Al-Razi, Tafsir al-Fakhr al-Rāzì, Beirut: Dār al-Fikr, 1981/1401, 141.

${ }^{86}$ Jamal Mohamed Mohamed al-Hanidi, Tarbiyah 'Ulamā' al-Tabí'iyyah..., vol. 1, 90. 


\section{To seek for prosperity in the earth}

The second responsibility of man on the environment is to seek for prosperity in the earth and manages it for the benefit of all creatures (Hūd: 61, al-Jāthiyah: 12-13, Zukhruf: 13, Luqmān: 20, al-Hajj: 65, alNaḥl: 11-14 and Ibrāhim: 32-34). Some scholars inferred from these verses that Islam is not give good position to the environment to put the environment under takeover of human being. Such conclusion is a mistake, if we look carefully the verses explain that the relationship between human and environment is not an ownership model that human can exploit the world as he wants, but is to support human position as successor of God in the earth. The relation is based on that God give human ability and capacity and they should treat and manage the universe and its resources based on God principles. They can harness and exploit the resource to comply with his job as the Successor of God in the earth for the interests of all beings. ${ }^{87}$

The Quran mentions that human and environment is an integral part of the universe to support each other. The Quran mention that nature and human being as 'abd and ummah of Allah, in the sense that human beings and the environment on the same level of his creatures which praise god in every time (al-Taghabun: 1, al-Hashr: 24, al-Nūr: 41-42, al-Isrā': 14 and al-An'ām: 18).

The difference between human and other organisms is his position as successor of God in the earth to his advantage with a mind and free will. Muhammad Rasyid Ridha said that human has also physiological advantage in the installation of his body. ${ }^{88}$ And with all these advantages human could be successor of God in managing the universe for

\footnotetext{
${ }^{87}$ Ibrahim Ozdemir, "Toward and Understanding of Environmental Ethics from Quranic Perspective"..., 7.

${ }^{88}$ Rashid al-Hamd and Mohammed Saeed Sabarini, 'Alam Ma'rifah ..., 92.
} 
the benefit of human beings and all creatures, because the earth is not created only for human but also for all creatures. ${ }^{89}$ Thus, the utilization of the resources of the universe in Islam is a right for all the people and for all type of creatures. ${ }^{90}$ We also aware that to seek the prosperity in the world does not only include land use and consumption but also include the care and preservation of the environment so that it does not cause shortages and attrition of resources for the next generation. On this context, the Quran condemn extravagance and wasteful use of resources, two of the bad behaviour (al-Mu'min: 43 and al-Isrā': 27). ${ }^{91}$ Therefore the exploitation of resources and the environment without attention the continuation for the next generation is opposite to the Quran and unjust to the environment.

\section{To maintain the balance of the environment}

The third responsibility is to maintain the balance of the environment. God has created the universe in a balance system, you will not find in God's creation disparity (al-Mulk: 3, al-Sajdah: 5-7 and al-Naml: 88). This balance shows the greatness of the creator of the universe, the vast universe does not varies each other but complement each other. God created the universe through all this harmony (Zukhruf: 32).

God has repaired the creation from the beginning and this balance is a blessing from God for the universe. Based on this, the mission of human being is to preserve this balance. Yusuf Qardhawi said that keeping the balance of the environment is part of the Necessary Five. Because the corruption of environment will affect human life, if environment rotted than it will cause damage to the surrounding

${ }^{89}$ Ibnu Katsir, Tafsirr al-Qur'ān al-Karïm..., 315.

${ }^{90}$ Abdullah Shehata, Ru'yah al-Din al-Islāmì fi al-Huffāza al-Bi'ah, Beirut: Dār al-Shuruq 2001/ 1421, vol. 1, 19.

${ }^{91}$ Saleh bin Abdullah Ibnu Hamid, Mawsūah Nadrah Na'im, Dār Wasilah, 4112, 4884. 
neighbourhood, and will spoil human being and its offspring. ${ }^{92}$ This is what the Quran warned in al-A'rāf: 53. God's command not to spoil the environment because it is been created for righteousness. Abu Hayyan said that the prohibition on corruption in this previous verse includes corrupting souls, genealogy, and corrupting minds and religions ${ }^{93}$ include physical and moral damages. Everything that affects and perishs the balance of the environment is forbidden, and the corruption of the environment is injustice, and this what was worried by the devil when God appointed human being as Khalifa (al-Ahzāb: 72) because injustice will cause suffering and human disasters (al-Kahf: 59, al-Naml: 52, Āli-'Imrān: 11).

Qardhawi said that injustice is a sin that the punishment is accelerated in this life particularly injustice towards the vulnerable. ${ }^{94}$ Every disasters and suffering wounded the human being are because of the oppressors. The Quran order human being to repair and improve the land (al-Mā'idah: 93). The injustice is in contrary to charity and justice, and in this regard Ibn Taymiyyah said that God keeps the infidel state if is fair but removes the Muslim state If it is unfair. ${ }^{95}$

\section{Conclusion}

After looking at the concept of human being and the concept of the environment in the Quran and human responsibility for the environment we can conclude that the Quran has mentioned various words that represent human that indicate the comprehensiveness position of human as individual and social creature as well as its mental and physical strength. The purpose of the creation of man is to worship God

\footnotetext{
${ }^{92}$ Yusuf al-Qardhawi, Ri'āyatul Bi'ah fi Shari'ah al-Islām, Dār al-Shuruq, 2001, vol. 1, 44- 53.

${ }^{93}$ Yusuf al-Qardhawi, Ri'āyatul Bi'ah..., 52.

${ }^{94}$ Yusuf al-Qardhawi, Ri'àyatul Bi'ah..., 225.

${ }^{95}$ Yusuf al-Qardhawi, Ri'ayyatul Bi'ah..., 226.
} 
alone and become successor of God on earth with responsibility in managing the earth and taking care of the environment for the interests of the creatures. The Quran defines environment in a large scale that cover all creatures in the heavens and the earth and what is between them. And dependence relation between human and environment indicates a strong relationship between them. Islam has concerned to the environment preservation as one of human being responsibilities as successor (khalifa) of God in the earth. It is human responsibility towards the environment to reflect and forethought, and to maintain the balance of the environment for the interests of all creation.

\section{Bibliography}

Abdillah, Mujiono. Agama Ramah Lingkungan Perspektif al-Qur'an. Jakarta: Paramadina, 2001.

Agus R dan Rudi S., Global Warming Mengancam Keselamatan Planet Bumi!!!", (www.hiduplebihmulia.wordpress.com)

Al-Baghawi. Ma'ālim al-Tanzïl. Riyadh: Dār Ṭayyibah, 1409 H.

Al-Baqi, Mohammad Fuad Abdul. Mu'jam Mufahras li Alfāz al-Qur'ān. Cairo: Dar Kutub Misriyyah, 1964.

Al-Damgani, Abi 'Abdullah al-Hussein Bin Mohammed. Al-Wujūh wa alNaz̧ā'ir. Beirut: Dār Kutub al-'Ilmiyyah, NA.

Al-Hamd, Rashid, and Mohammed Saeed Sabarini. Alam Ma'rifah No. 22: al-Bi'ah wa Mushkilatihā. Kuwait: al-Majlis al-Awatthānì li alThaqafah wa al-Qanūn wa al-Adab, 1979.

Al-Hanidi, Jamal Mohamed Mohamed. Tarbiyah 'Ulamā'al-Tabíliyyah wa al-Kawniyyāt al- Muslimin fi al-Qurūn al-Khamsah al-Ūlā min alHijrah. Dār al-Wafā, 1421 H/ 2001 M. 
Al-Isfahani. Al-Mufradāt li Gharīb al-Qur'ān. Beirut: Dār al-Ma'rifat, NA. Al-Isfahani. Mu'jam Mufradāt li Alfāz al-Qurāan. Beirut: Dār al-Kutub al'Ilmiyyah, $1420 \mathrm{H} / 2004 \mathrm{M}$.

Al-Isfahani. Mufradāt Alfāẓ al-Qur'ān. Beirut: Dār al-Shamiyyah, 1992. Al-Razi. Tafsir al Fakhr al-Rāzì. Beirut: Dār al-Fikr, 1981/1401.

Al-Sinqiti. Adwā'al-Bayān fi Iydah al-Qur'ān bi al-Qur'ān. Beirut: Dār alFikr, 1995.

Al-Sayyid Al Jamili. Al-Islām wa al-Bi'ah. Markaz al-Kitāb li al-Nasyr, 1996.

Al-Qasimi. Maḥasin al-Ta'wïl. Cairo: Dār al-Iḥyā' al-Kutub al-'Arabiyah.

Al-Qardhawi, Yusuf. Ri'āyah al-Bi'ah fi Sharìah al-Islām. Dār al-Shuruq, 2001.

Al-Wahidi. Asbāb al-Nuzūl. Beirut: Dār al-Fikr, 1994.

Al-Zuhaily, Wahbah Bin Musthafa. Al-Tafsir al-Wasit I al-Zuhayli. Damascus: Dār al-Fikr, 1422.

Al-Zuhaily, Wahbah Bin Musthafa. Al-Tafsir al-Munir fi al-Aqidah wa alSharìah wa al-Manhaj. Damascus: Dār al-Fikr al-Mu'āṣirah, 1418. Al-Zarkasyi. Al-Burhān fi 'Ulūm al-Qur'ān. Cairo: Dār al-Iḥyā' al-Kutub al-`Arabiyah, NA.

Baiquni, Achmad. Al-Quran Ilmu Pengetahuan dan Teknologi. Yogyakarta: Dana Bahkti Wakaf, 1993.

Binti Syathi. Al-Qur'ān wa Qaḍāyā al-Insān. Cairo, Dār al-Ma'ārif, NA.

Ekad, Mahmoud. Al-Islām wa al-Insān. Dār Fuṣṣilat li al-Dirāsāt wa alTarjamah wa al-Nashr, 1999 M-1419 H.

Foltz, Richard C. et. al. Islam and Ecology: A Bestowed Trust. Cambridge : Harvard University Press, 2003. 
Husada et. al. Kajian Islam Kontemporer. Jakarta: UIN Jakarta Press, 2007.

IPCC. Climate Change 2007: The Physical Science Basis. Contribution of Working Group I to the Fourth Assessment Report of the Intergovernmental Panel on Climate Change. Cambridge: Cambridge University Press, 2007.

Ibnu Hamid, Saleh bin 'Abdullah. Mawsü'ah Nadrah al-Na'im. Dār Wasilah, NA.

Ibnu Faris. Mu'jam Maqāyis al-Lughah. Cairo: Maktabah al-Khabkhi, $1402 \mathrm{H} / 1981 \mathrm{M}$.

Ibnu Katsir. Tafsir Ibn Kathïr. Beirut: Dār al-Fikr, 1986.

Ibnu Mandzur. Lisān al-'Arab. Beirut: Dār al-Ṣadr, 1410 H/1990 M.

Jamā'ah Min Kibār al-Lughawiyyīn al-'Arab. Al-Mu'jam al-'Arabï al-Asasï. Al-Munaz̧zamahah al-'Arabiyyah li Tarbiyah wa Thaqāfah wa al-'Ulūm, 1424/2003.

Jirah, Abdul Rahman. Al-Islam wa al-Bi'ah. Dār al-Salām li al-Ṭibā'ah wa al-Nashr wa al Tawzi' wa al-Tarjamah, 1420 - 2000.

Knight, Lindsay (ed.) World Disaster report 2009, Focus on Early Warning, Early Action. International Federation of Red Cross and Red Crescent Societies, 2009.

Mohammed, Hamad Salamah. Muqtarah Istirātijiyyah li Idārah alAnsyitāat al-Ta'diniyyah bi al-Muhammiyah al-Ṭabí'iyyah. Al-Idārah al-Markaziyyah li Himāyah al-Ṭabi'iyyah Juhaz Shu'ūn al Bi'ah, Wuzārah al-Dawlah li Shu'ūn al-Bi'ah, NA.

Ozdemir, Ibrahim., "Toward and Understanding of Environmental Ethics from Quranic Perspective" in Islam and Ecology a Bestowed Trust. Harvard: Harvard University Press, 2003. 
Ridha, Muhammad Rashid. Tafsiri al-Manār. Cairo: Dār al-Manār, 1948.

Shehata, 'Abdullah. Ru'yah al-Din al-Islāmì fi al-Huffäz al-Bi'ah. Beirut: Dār al- Shuruq 2001.

Shaltout, Mohammed. Tafsir al-Qur'ān al-Karìm. Beirut: Dār al-Qalam, 1965.

Wuzārah al-Tarbiyyah wa al-Ta'lim. Istinzāâf al-Mawārid al-Ṭabīíyyah. Sultanah Oman, 2008.

Sardar, Ziauddin. Islamic Futures. New York: Mansell Publishing Limited, 1985.

Shihab, M. Quraish. Tafsir al-Mishbah: Pesan, Kesan dan Keserasian al-Qur'an. Jakarta: Lentera Hati, 2007.

Shihab, M. Quraish. Membumikan al-Qur'an: Fungsi dan Peran Wahyu dalam Kehidupan Masyarakat. (Bandung: Mizan, 1997.

Tacconi, Luca, Occasional Paper no 38i "Kebakaran Hutan di Indonesia: Penyebab, Biaya dan Implikasi Kebijakan", Center for International Forestry Research/CIFOR 2003. 